УДК 633. 15:631.5

Писаренко В. М., доктор сільськогосподарських наук,

Писаренко П. В., доктор сільськогосподарських наук,

Писаренко В. В., доктор економічних наук,

Горб О. О., кандидат сільськогосподарських наук,

Чайка Т. О., кандидат економічних наук

Полтавська державна аграрна академія

\title{
ПОСУХИ В КОНТЕКСТІ ЗМІН КЛІМАТУ УКРАЇНИ
}

\section{Рецензент - доктор сільськогосподарських наук М. Я. Шевніков}

Мета статmі - довести необхідність впровадження системних і науково обтрунтованих заходів з адаптації аграрного виробництва до нових кліматичних умов у зв'язку зі збільшенням повторюваності посух.

Методика дослідження. Методологічною основою дослідження слугували такі наукові методи: історико-діалектичний, аналізу і синтезу, теоретичний пошук і абстрактно-логічний, математичного та статистичного аналізу на основі результатів досліджень, що проведені на сільськогосподарських угіддях ПП «Агроекологія».

Результати дослідження. Досліджено теорії змін клімату, з якими пов'язані посухи: вплив сонячної активності, вплив космічних факторів, антропогенний вплив на природу. Обтрунтовано доцільність розробки адаптаційних заходів у технології сільськогосподарського виробнищтва, що дозволять зменшити негативний вплив погоди, та технологічні заходи з накопичення, збереження і раціонального використання вологи, особливо в умовах посух. Показано вплив на збереження вологи, урожайність і рентабельність аграрного виробництва різних систем землеробства: інтенсивної, органічної, no-till, strip-till, точного землеробства, біоензимної технології, біогенного землеробства. Доведено, що в умовах змін клімату актуальності набувають дослідження вологозберігаючих систем землеробства, однією з яких є органічне землеробство.

Елементи наукової новизни. Визначено особливості агротехнічних прийомів, щзо сприяють накопиченню, збереженню та рачіональному використанню трунтової вологи, за умов різних систем землеробства.

Практична значущість. Проведені дослідження впливу висоти снігового покриву на запаси вологи у метровому шарі трунту за системи органічного землеробства, щзо свідчить про значну роль снігозатримання. Розкрито доцільність регулювання вологозабезпечення культур таких агротехнологічних заходів: створення куліс для затримки снігу, використання лісосмуг, впровадження сівозмін, правильне структурування посівних площ, мінімальний обробіток трунту, використання органічних добрив, мульчування поверхні поля.

Ключові слова: посуха, зміна клімату, вологозабезпечення трунту, урожайність, сільськогосподарські культури, органічне землеробство, нульовий обробіток трунту, система смугового землеробства, система точного землеробства, біоензимна технологія, біогенне землеробство.

Писаренко Віктор Микитович - доктор сільськогосподарських наук, професор, завідувач кафедри захисту рослин, заслужений діяч науки і техніки України, Полтавська державна аграрна академія, вул. Сковороди, 1/3, м. Полтава, 36003, Україна, e-mail: kafedra.zahystu-roslyn@ukr.net, ORCID 00000002-4915-265X.

Писаренко Павло Вікторович - доктор сільськогосподарських наук, професор, професор кафедри екології, збалансованого природокористування та захисту довкілля, перший проректор, академік інженерної Академії наук України, Полтавська державна аграрна академія, вул. Сковороди, 1/3, м. Полтава, 36003, Україна, e-mail: pavlo.pysarenko@pdaa.edu.ua, ORCID ID: 0000-0002-4915-265X.

Писаренко Володимир Вікторович - доктор економічних наук, професор, завідувач кафедри маркетингу, Полтавська державна аграрна академія, вул. Сковороди, 1/3, м. Полтава, 36003, Україна, e-mail: volodymyr.pysarenko@pdaa.edu.ua, ORCID ID: 0000-0002-9484-3476.

Горб Олег Олександрович - кандидат сільськогосподарських наук, доцент, професор кафедри екології, збалансованого природокористування та захисту довкілля, проректор із науково- 


\section{СІЛЬСЬКЕ ГОСПОДАРСТВО. ЕКОЛОГІЯ}

педагогічної, наукової роботи, член-кореспондент інженерної Академії наук України, Полтавська державна аграрна академія, вул. Сковороди, 1/3, м. Полтава, 36003, Україна, е-mail: gorb@pdaa.edu.ua, ORCID ID: 0000-0002-3141-8114.

Чайка Тетяна Олександрівна - кандидат економічних наук, начальник редакційно-видавничого відділу, Полтавська державна аграрна академія, вул. Сковороди, 1/3, м. Полтава, 36003, Україна, e-mail: chayka_ta@ukr.net, ORCID ID: 0000-0002-5980-7517.

Постановка проблеми. Однією 3 важливих екологічних проблем XXI століття є зміна загальнопланетарного клімату. На сьогодні існує велика загроза недостатнього розуміння та недооцінки впливу цього явища. Глобальне потепління, яке метеорологи визначають як підвищення середньорічної температури повітря й усієї кліматичної системи, розпочалося в 70-ті роки минулого століття, уже зараз, а тим більше у недалекому майбутньому, неодмінно впливатиме на землеробство планети.

Особливо зміна клімату впливатиме на гідротермічний режим грунту під час вегетаційного періоду сільськогосподарських культур. Водночас прямим наслідком змін клімату є посухи, які негативно впливають на урожайність культурних рослин в Україні, оскільки погодна складова врожаїв у нашій державі становить понад $50 \%$ [7]. При цьому необхідно зазначити, що в останні десятиліття відмічається небезпечна тенденція до збільшення повторюваності посух.

Під терміном «посуха» розуміють нестачу чи відсутність опадів протягом тривалого періоду часу при підвищених температурах повітря та зниженні його волості, внаслідок чого зменшуються запаси вологи в грунті.

У зоні Лісостепу на кожний квадратний метр земної поверхні у формі снігу та дощу надходить 450-600 л води, але попри це, сюди все частіше протягом останніх років, у зв'язку з глобальним потеплінням, приходять посухи. Вони проявляються, щонайбільше, як нерівномірні надходження води на поля протягом вегетаційного періоду. В останні десятиліття кількість вологи, що надходить на територію України, не зменшилася, але змінився характер атмосферних опадів. Останнім часом дощі випадають істотно рідше й часто мають зливовий характер. Кількість води, що надходить на поля у дуже короткий проміжок часу, фізично не може бути поглинута орним шаром і стікає, збільшуючи ерозію грунту.

Тому найважливішим завданням землекористувачів $\epsilon$ пошук та впровадження ефективних прийомів із накопичення й раціонального використання наявних запасів вологи у грунті.

Аналіз основних досліджень і публікацій, у яких започатковано розв'язання проблеми.
Необхідно зазначити, що проблема вологозабезпечення рослин завжди хвилювала науковців і виробників, тому проводився постійний пошук прийомів для створення сприятливого водного режиму грунту. Ще у вісімнадцятому столітті вчений агроном О. О. Ізмаїльський у своїй добре відомій аграріям книзі «Как высохла наша степь» писав: «Все заботы хозяина должны быть сведены к единственной цели - по возможности увеличить ту часть атмосферной влаги, которая впитывается почвой, соотвествено уменьшая количество атмосферной влаги, бесполезно стекающей с поверхности почвы» [12].

Тоді ж директор Полтавського дослідного поля Б. П. Черепахін наголошував, що в умовах Лісостепу ефективність землеробства грунтується на вологозабезпеченні грунту, наголошуючи при цьому «...все во влаге, все для влаги, всё ради влаги». У зв'язку з глобальним потеплінням ці думки класиків землеробства набувають актуальності.

Мета дослідження - обгрунтувати необхідність впровадження системних i науковообгрунтованих заходів з адаптації аграрного виробництва до нових кліматичних умов у зв'язку зі збільшенням повторюваності посухи. Завдання дослідження - встановити вплив технологій сільськогосподарського виробництва на вологозабезпечення грунту та врожайність культур.

Матеріали і методи досліджень. Для визначення причин збільшення повторюваності посухи було проведено огляд літератури з теорії змін клімату. Проведено аналіз та узагальнено дослідження щодо впливу різних систем землеробства на вологозабезпеченість грунту та врожайність. Наведено результати польових досліджень за 2017-2018 pp. на полях ПП «Агроекологія» (Шишацький і Зіньківський райони Полтавської області) щодо впливу висоти снігового покриву на запаси вологи у метровому шарі грунту.

Результати досліджень. На сьогодні існує три теорії змін клімату, з якими пов'язані посухи. Деякі вчені-кліматологи вважають, що коливання клімату (цикли) вірогідно пов'язане із впливом сонячної активності, тобто з тими внутрішніми процесами, в результаті яких на Сонці з'являються плями, що є гігантськими електро- 


\section{СІЛЬСЬКЕ ГОСПОДАРСТВО. ЕКОЛОГІЯ}

магнітними вихровими утвореннями. Кількість $\mathrm{i}$ розміри їх не завжди однакові. Мінливість кількості сонячних плям має відносно упорядкований характер, вона проходить хвильовим чином.

Зараз виявлено тісний зв'язок між сонячною активністю та фізичними процесами у верхніх шарах атмосфери, але вчені вважають, що сонячна активність ефективно впливає i на нижню частину атмосферної оболонки Землі. Х. П. Погосян [17] пише: «Не підлягає сумніву, що вікові коливання клімату, відбуваються внаслідок змін характеру загальної циркуляції атмосфери. Так само характер циркуляції, вочевидь залежить від сонячної активності та інших астрономічних явищ».

Отже, вікові коливання клімату відбуваються внаслідок змін характеру загальної циркуляції атмосфери. I. Є. Бучинський [6] вважає, що коливання клімату звичайне явище в природі, має відносно упорядкований характер i проходить хвильовим чином. Воно викликає у багатьох людей уявлення, нібито клімат «на наших очах» змінюється. Однак це удавана зміна клімату, це є тільки його «закономірне» коливання, а не стійка зміна в одному напрямі.

Базуючись на основах метеорологічної концепції нелінійних процесів і передбачуваності поведінки складних природних систем у майбутньому, Є. М. Білецький і С. В. Станкевич [4] практично схиляються також до того, що посухи $\epsilon$ звичайним явищем у природі, обумовленим коливанням клімату. При цьому вони зазначають, що масштабні природні катаклізми, які циклічно проходять на планеті, уже неодноразово траплялися в історії Землі і людської цивілізації.

Міжнародна група вчених вважає, що глобальне потепління, викликане зміщенням геомагнітних полюсів земної осі, на які впливають космічні фактори. Внаслідок цього планета злегка уповільнила свої оберти, приблизно на секунду в рік. За рахунок втрати цієї секунди кількість теплової енергії, яка виділяється, перевищує всю енергію, яку виробляє людство в результаті своєї діяльності протягом року. Це спричинило зміни альбедо планети, iii орбітальних параметрів, підвищення приземної температури, що серйозно впливає на зміну клімату, виникнення загрозливих гідрометеорологічних явищ, одним 3 яких $\epsilon$ посухи.

Проте зміщення геомагнітних полюсів земної осі принесли не лише більшу кількість тепла. Одночасно проявляються зміни «рози вітрів»як результат трансформації глобальної циркуляції повітряних мас на планеті, у Свропі і в нашій країні зокрема [13]. Зміна геомагнітних полюсів впливає на морські течії, головне з яких Гольфстрім, швидкість течії якого уже зараз уповільнилася на 20 \%, що також впливає на клімат Свропи. Повітряні маси, що насичені вологою 3 просторів Атлантичного океану, насамперед з теплої течіiі Гольфстріму, рухаючись над просторами Європи у східному напрямку, поступово зрошують землю відносно регулярними дощами. Рух таких повітряних мас $є$ своєрідною перешкодою для вторгнення в нашу країну холодного повітря 3 Арктики (північний напрямок), або гарячого й сухого 3 континентальних глибин Азії або Африки (східний і південний напрямки). Ослаблення тиску повітряного потоку зі сторони Гольфстріму, можливо є однією з причин проникнення цих повітряних течій, які сприяють підвищенню температури та посухам [13].

Ще однією $з$ теорій глобальних змін клімату на планеті кліматологи вважають антропогенний вплив на природу. Вченими доведено, що зміни, свідками яких ми є зараз, та які прогнозуються в майбутньому, багато в чому є наслідками людської діяльності: ми спалюємо викопне паливо, зростають викиди транспортної індустрії та масштаби інтенсивного сільського господарства. Значне збільшення виробничих викидів «підігріває» нашу атмосферу, в ній стрімко зростає кількість «парникових» газів (вуглекислий газ, метан, оксиди азоту, хлорфторвуглеводні гази тощо).

При цьому необхідно зазначити, що «парникові» гази нашої планети працюють за принципом теплиці: пропускають видиме світло до поверхні, а теплове випромінювання утримують у середині. У результаті цього температура на поверхні Землі $є$ придатною для життя. Але чим більше «парникових» газів в атмосфері, більше тепла затримується біля поверхні Землі.

Отже, діяльність людини підсилює «парниковий» ефект, у результаті чого збільшується приземна температура повітря, i 3 агрономічного погляду Лісостеп України стає класичною зоною посушливого клімату та взагалі розширюються зони ризикованого землеробства.

Цілком ймовірно, що вплив космічних i антропогенних факторів на клімат планети має комплексний характер, посухи (весняні, літні або осінні) стануть частим явищем. Тому сьогодні глобальне потепління розглядають як факт, і головною проблемою при цьому стає дефіцит вологи, їі накопичення, збереження і раціональне використання.

Отже, насамперед необхідно розробити адаптаційні заходи до негативного впливу погоди, 


\section{СІЛЬСЬКЕ ГОСПОДАРСТВО. ЕКОЛОГІЯ}

які повинні органічно увійти в технології сільськогосподарського виробництва. По-друге, це впровадження технологічних заходів із накопичення, збереження і раціонального використання вологи, особливо в умовах посух.

До першої групи заходів, які можуть протистояти кліматичним негараздам, можна віднести: розробку нового районування території; використання посухостійких сортів і гібридів сільськогосподарських культур, адаптованих до значно меншого вегетаційного періоду; впровадження нових (нішевих) посухостійких культур; застосування антистресових хімічних, біологічних i мікробіологічних препаратів, комплексних мікродобрив; внесення перегною та компостів; використання гуматів, мінералів (бентоніт тощо); контроль за фітосанітарним станом посівів сільськогосподарських культур та інше.

За даними НААН України, за останні десятиліття відбувається фактичне зміщення меж природно-кліматичних зон країни на 100-150 км на північ. Умови вегетації у традиційній підзоні Північного Степу (Дніпропетровська, Кропивницька області та ін.) вже відповідають підзоні Південного Степу. Підзона Північного Степу поступово зміщується на території Черкаської, Полтавської та інших областей, які традиційно були в зоні Лісостепу $[14,18]$.

У таких умовах змінюється нині існуючий зональний набір сільськогосподарських культур. Передусім бачимо, крім основних культур (пшениця озима, кукурудза, соняшник), так звані нішеві культури (нут, сочевиця, сафлор, сорго, просо тощо), які мають високу посухостійкість та експортну спроможність. У зв'язку з потеплінням на Півдні України почали вирощувати екзотичні культури: ківі, хурму, бананове дерево, зизифус (китайський фінік або унабі), арахіс, батат, чорний перець. Приживаються оливкові дерева.

По-друге, в умовах підвищеної посушливості клімату, волога визначає рівень урожайності. Тому, у зв'язку зі збільшенням ролі вологи, як лімітуючого фактора в отриманні урожаю, змінюються стереотипи оцінки ефективності систем землеробства і технологій вирощування сільськогосподарських культур. Нагальним стає вивчення та впровадження у виробництво технологічних прийомів і систем землеробства, які дозволяють на рівні існуючого вологозабезпечення отримувати заплановані урожаї.

Зростає потреба у накопиченні вологи у грунті в осінньо-зимовий і весняний періоди, які здатні значною мірою, при раціональних витратах, забезпечити фізіологічні потреби сільськогосподарських рослин під час вегетації, у періоди між дощами, коли трапляються посухи.

Спочатку необхідно зазначити, що найбільш значними для насичення грунту водою можна вважати атмосферні опади, що досягли його поверхні (кожен міліметр опадів утворює 10 т води на 1 га).

За останні 20 років середньорічна температура січня та лютого підвищилася на $1-2{ }^{0} \mathrm{C}$, що призвело до змін у ритмі сезонних явищ - значно збільшилася кількість опадів у осінньозимовий період. Тому одним із важливих джерел водопостачання у грунт $є$ надходження води 3 талого снігу. У зв'язку з цим значно зростає роль снігозатримання.

На полях ПП «Агроекологія» (Шишацький i Зіньківський райони Полтавської області) проведено дослідження впливу висоти снігового покриву на запаси вологи у метровому шарі грунту. Обліки проводили на полях соняшнику, де були залишені стебла на зиму з метою створення куліс для снігозатримання (цей прийом входить до технологій органічного землеробства) та на інших полях. У 2017 р. максимальний сніговий покрив на соняшнику досягав 35 см, і запаси продуктивної вологи в метровому шарі грунту на початку вегетації становили 142 мм. На полі, де була стерня ячменю з еспарцетом першого року життя, ці показники становили відповідно 25 см i 110 мм. На полі еспарцету 3 отавою снігу та вологи було 37 см і 121 мм відповідно. На посіві пшениці озимої було накопичено 20 см снігу i 99,4 мм вологи. Проведені у 2018 р. обліки показали ту ж тенденцію, але із більшими запасами снігу та вологи. По залишеним стеблам соняшнику при висоті снігового покриву 47 см, запаси вологи досягли 167 мм. Отже, снігозатримання $є$ важливим прийомом накопичення вологи у грунті.

При цьому ми в жодному разі не зменшуємо вплив інших агротехнічних прийомів, зокрема $\mathrm{i}$ лісових смуг на вологозабезпечення грунту. Адже, займаючи всього 1,4 \% орних земель, захищаючи поля від посух та ерозіі, вони підвищують урожайність сільськогосподарських культур у середньому на 15-20\%.

Розглянемо також основні елементи інтенсивної системи землеробства у контексті вологозбереження та раціонального використання вологи [19]. Серед них: структура посівних площ, науково-обгрунтоване чергування культур у сівозмінах, раціональні системи обробітку грунту 3 урахуванням їхньго впливу на збереження i 


\section{СІЛЬСЬКЕ ГОСПОДАРСТВО. ЕКОЛОГІЯ}

раціональне використання вологи, прийоми догляду за рослинами, удобрення, боротьба зі шкідниками та хворобами рослин, використання сучасної сільськогосподарської техніки.

Структура посівних площ визначається плановими завданнями виробництва сільськогосподарської продукції i, за умови правильної побудови, слугує одним із важливих заходів боротьби 3 посухою, шляхом більш раціонального використання опадів протягом вегетаційного періоду. Озимі й ранні ярові культури більш повно використовують осінньо-зимові запаси вологи, а також опади травня і червня. Опади двох наступних літніх місяців зернові й зернобобові, що дозрівають до цього часу, не використовують зовсім. Просапні культури краще засвоюють літні опади. 3 огляду на це, можна доцільніше підібрати культури в сівозміні.

Важлива роль у регулюванні вологозабезпечення культур належить сівозміні. Сільськогосподарські культури істотно відрізняються за вибагливістю до грунтової вологи і мають різний вплив на водний режим грунту. Для спрямованого регулювання водного режиму в системі грунтрослина необхідно таке чергування культур у сівозмінах, при якому раціональне використання рослинами грунтової вологи поєднується 3 наступним відновленням iii запасів у відповідних шарах грунту.

3'ясовано, що під такими культурами як кукурудза і пшениця озима та після зайнятих парів, досить добре відновлюються запаси продуктивної вологи у глибоких шарах грунту. Тому ці культури доцільно розміщувати у сівозміні після культур із глибоко проникаючою кореневою системою, які висушують грунти на велику глибину, для того щоб відновити запаси вологи у цих горизонтах.

Досліджуючи вплив обробітку грунту на його водний режим, необхідно зазначити, що традиційний обробіток грунту, головним видом якого $\epsilon$ оранка, впродовж багатьох десятиліть дозволяв забезпечувати людство продовольством, але одночасно створив безліч негараздів, пов'язаних із ерозією грунтів, погіршенням їх якості та висушуванням [28]. Завданням сучасної системи обробітку грунту є інтенсифікація виробництва й одночасне збереження існуючих природних систем, максимальне накопичення та раціональне використання вологи, яка надходить у грунт. Плуг відходить на другий план, тоді як на перший виходять знаряддя, які лише розпушують верхній шар грунту, що допомагає зберегти більше вологи в орному шарі, скоротити строки посіву i, що не менш важливо, економити енергоресурси.

Позитивні результати, попри погодні катаклізми, мають ті господарства, які враховують кліматичні зміни, і замість глибокої оранки проводять глибоке рихлення грунту або його поверхневий (мілкий) обробіток, що має більший ефект у накопиченні, збереженні та використанні вологи. Річний вологонакопичувальний ефект його порівняно 3 оранкою вищий на 30-50 мм, що особливо важливо під час посухи.

У зв'язку з цим важливо зазначити, що у природі існує свій «біологічний» плуг. Неоране поле пронизане мільярдами капілярів, що залишаються після кореневої системи, а також утворюються в результаті життєдіяльності дощових черв'яків та інших організмів.

По цих капілярах грунт насичується вологою. Перехід на мінімальний, а потім нульовий обробіток, не руйнує цю природну структуру, залишає на поверхні пожнивні рештки (мульчу), які захищають грунт від перегріву в період посухи, зменшують кількість проростків насіння бур'янів та ерозію грунту.

У системі обробітку грунту розглядаються також: своєчасне проведення післязбирального лущення, передпосівна підготовка, міжрядні культивації просапних культур з метою рихлення грунту та боротьби з бур'янами тощо. Усі ці технологічні заходи впливають на збереження $\mathrm{i}$ раціональне використання вологи. Наприклад, своєчасне лущення стерні зберігає до 40 мм вологи у метровому шарі грунту. Бур'яни залежно від виду поглинають до $130 \mathrm{Mм} / \mathrm{M}^{2}$ вологи 3 грунту, тим самим позбавляючи культурні рослини доступної вологи, тому боротьба з ними має важливе вологозберігаюче значення. Значну роль у збереженні вологи мають заходи боротьби з ерозією грунту.

У продуктивному використанні вологи також важливу роль мають добрива. Кожна тонна внесеного у грунт гною за роки його дії в багатопільній сівозміні дає додатково до 1 ц у перерахунку на зерно, а кожен центнер мінеральних добрив у стандартних туках, при їх внесенні під основні польові культури (пшениця озима, кукурудза, ячмінь, просо) - в середньому до 1,5 ц зерна. Зрозуміло, що в ефективності добрив важливу роль відіграє вологість грунту. Наприклад, відомо, що кожен додатковий міліметр грунтової вологи може підвищити на 0,5 т/га врожай, а в період посухи додаткові 2,5 мм води приводять до додаткового збільшення врожайності кукурудзи на $0,5-0,7$ т/га [11]. 


\section{СІЛЬСЬКЕ ГОСПОДАРСТВО. ЕКОЛОГІЯ}

Слід відмітити, що в умовах посухи використання органічних добрив, за рахунок яких збільшується органічна складова грунту, покращує його водний режим.

В умовах змін клімату - глобального потепління та збільшення частоти посухи, актуальними стають дослідження вологозберігаючих систем землеробства, однією 3 яких є органічне землеробство [3, 16], агротехнічні прийоми якого сприяють накопиченню, збереженню та раціональному використанню грунтової вологи.

Одним із технологічних елементів цього землеробства, що сприяє покращенню водного режиму, є грунтозахисний, вологозберігаючий, мілкий обробіток грунту на глибину 4-5 см, завдяки якому створюється вертикальна орієнтація пор аерації, зберігається природна структура грунту, його капілярність, сформована корінням, яке розкладається, та дощовими черв' яками. При такому обробітку відсутній горизонт ущільнення (плужна підошва), встановлюється баланс великих і малих пор, які зберігають повітря та вологу, створюючи умови для атмосферної іригації. Практично реалізується запропонована понад сто років тому І. Овсінським ідея «сухого землеробства» 3 максимальним залученням у технології землеробства «ефекту підгрунтової роси». Цей обробіток також позитивно впливає на розвиток мікоризи [27], яка сприяє росту рослин у посушливих умовах.

Накопиченню вологи сприяє також дотримання науково обгрунтованих сівозмін, уведення у структуру посівних площ багаторічних бобових трав, сидератів, внесення перегною, використання пожнивних решток, нетоварної частини врожаю. Завдяки цьому у грунті збільшується органічна маса, яка робить грунт більш рихлим і підвищує здатність утримувати вологу. Мульчування поверхні поля рослинними рештками також сприяє зниженню температури грунту i випаровуванню вологи. Отже, за органічного землеробства вологість грунту в різні періоди вегетації рослин у середньому на 28-32 \% більша від грунту, на якому ведеться інтенсивне землеробство.

Крім того застосування технологій органічного землеробства позитивно позначається на показниках структурно-агрегатного стану грунту. У шарі 0-10 см за органічної системи коефіцієнт структурності грунту становив 9,9, що майже удвічі вище порівняно 3 контрольним варіантом (інтенсивна система) - 4,62. 3 глибиною його значення знижується, особливо це стосується товщі грунту 30-50 см.

Застосування органічної системи землеробст- ва сприяє також зростанню коефіцієнта водостійкості структурних агрегатів. Коефіцієнт водостійкості структурних агрегатів за органічної системи землеробства дорівнював 10, а при інтенсивній $-5,2$.

При тривалому застосуванні органічних технологій також виявлена тенденція зміни параметрів водотривкої частини грунту - гумусу. У шарі грунту 10-20 см вміст загального гумусу за органічної системи становив 5,26\%, за мінеральної - 4,70 \%. На окремих полях за рахунок інтенсивнішої гуміфікації органічних решток він сягав різниці до $1,57 \%$, Особливо відчутний процес грунтоутворення на еродованих землях, урожайність яких, через певний період після впровадження системи, досягала показників на рівнинних полях.

Доповнює систему сучасний комплекс сільськогосподарських машин та механізмів для суцільного та міжрядного обробітку грунту.

Логічно, що підвищення родючості грунту позитивно впливає на продуктивність сільськогосподарських культур. Але якщо за умови нестачі вологи на цьому рівні родючості не може бути високого врожаю, то використання інтенсивних методів не збільшать їх. Та коли вирощена продукція сертифікована як органічна, є можливість отримати додатково 30-50\% і більше коштів від іiі реалізації.

Отже, широке впровадження органічного землеробства є оптимальною реакцією агропромислового комплексу на глобальне потепління, адже технології цієї системи дозволяють більш продуктивно накопичувати й використовувати вологу за рахунок сівозмін, мілкого обробітку грунту, внесення органічних добрив та вирощування сидератів, використання сучасних машин та механізмів для обробітку грунту. Це дозволяє отримувати екологічно безпечну продукцію, зберігати і навіть підвищувати родючість грунту (зберігати землю).

На жаль, розвиток наукових досліджень i впровадження в царині органічного землеробства як в нашій державі, так і за кордоном суттєво відстає від вимог виробництва. Саме дефіцитом знань і пояснюється те, що більшість виробників не наважуються розпочати впровадження системи органічного землеробства у своїх господарствах. Хоча ця система впроваджена і протягом 40 років успішно працює у всесвітньо відомому господарстві «Агроекологія», що на Полтавщині, засновником якого є Герой Соціалістої праці, Герой України Семен Свиридонович Антонець. Але, на жаль, доводиться погодиться зі словами 


\section{СІЛЬСЬКЕ ГОСПОДАРСТВО. ЕКОЛОГІЯ}

французького мікробіолога Луї Пастера, що «встановлена істина, навіть найбільш блискуча, не завжди легко визнається».

У зв'язку зі збільшенням посушливості клімату, й особливо у напівпустельних зонах і зонах ризикованого землеробства, актуальною $\epsilon$ система No-till, тобто нульовий обробіток грунту $[1,9]$. При впровадженні цієї системи поверхневий шар грунту не рихлиться, використовується прямий посів культур, поверхня грунту покривається шаром спеціально подрібнених рослин (мульчею). Ці заходи сприяють збереженню вологи, запобігають водній та вітровій ерозії.

Внесення добрив проводиться при сівбі у прорізані сівалкою посівні борозни. Контроль бур'янів базується на застосуванні гербіцидів у період, що передує посіву або після нього.

Головний принцип системи - використання природних процесів, які відбуваються у грунті. 3'ясовано, що неоране поле на 1-2 метри вглиб пронизане мільярдами капілярів, які утворюються після розкладання кореневої системи рослин та в результаті життєдіяльності різних організмів, насамперед, дощових черв'яків, кількість яких за умов цієї системи, значно зростає. По цих тонких, але глибоких ходах землю насичує волога. Взимку вона там замерзає і розширює канали. Так відбувається природне розпушування та насичення грунту водою і киснем, підтримання його у природному стані. Тому застосування «нульової» технології землеробства через певний час покращує фізичний стан грунту.

Одним із базових наукових положень при нульовому обробітку є обов'язкове залишення всіх рослинних решток на поверхні та їх рівномірне розміщення на полі. Мульча значно зменшує випаровування вологи (на 80 \%), а також сприяє конденсації вологи у вигляді роси (атмосферна іригація) при зіткненні атмосферного повітря 3 більш холодною поверхнею грунту.

Мульча також стримує ріст бур'янів, сприяє активізації мікрофлори грунту і $€$ базисом для відтворення його родючості. Ефект пригнічення проростання насіння бур'янів починає проявлятися, коли кількість пожнивних решток становить 3 т/га, зростає приблизно до $12 \%$ на кожні додаткові 100 кг решток.

Для покращення водного режиму грунту, зниження розвитку шкідників, хвороб та бур'янів, підвищення родючості та природного розущільнення грунту корінням рослин важливе значення має сівозміна. Щорічне чергування зернових і широколистих культур порушує цикл життєдіяльності шкідників і хвороб, а також значно зменшує проблему з бур'янами, з якими не впоралися гербіциди минулого року.

Рекомендується включати в сівозміну покривні та сидеральні культури з тим, щоб скоротити періоди відсутності на полях вегетуючих рослин i накопичити подушку з рослинних решток, поповнити грунт пожнивними речовинами та зменшити забур'яненість поля, поліпшити забезпеченість наступних культур вологою за рахунок створеної кореневою системою сидератів дренажної системи. Одними 3 кращих пожнивних сидератів $є$ капустяні культури (гірчиця біла, редька олійна тощо). Вони є корисними фітосанітарами та фітомеліорантами. Особливо є необхідними у сівозмінах, насичених злаковими культурами, забезпечуючи плодозміну.

Учені США $[9,20]$ відзначають, що ця технологія дає змогу зменшити обсяги використання гербіцидів за рахунок біорізноманіття культур у сівозміні, використання мульчі, посіву покривних культур, ефекту синергії та мікоризи. Ці заходи підвищують родючість грунту за рахунок мікробіологічної активності, збільшується вміст органічної речовини та підвищується стабільність грунтових агрегатів, що сприяє оптимізації фітосанітарного стану посівів.

Отже, використання «нульової» технології забезпечує збільшення кількості органічної речовини, покращує водний режим грунту, зменшує ерозійні процеси, що позитивно впливає на врожай та прибуток за рахунок ефективного використання вологи й покращення росту рослин.

Користь, яку землеробство отримує від впровадження no-till, буде залежати від типу грунту, клімату, культури, технологій рослинництва та менеджменту. Використання no-till підвищує рентабельність господарства. Порівнюючи «нульову» технології з традиційним обробітком, було виявлено, що кукурудза, олійні культури й сорго під no-till були більш прибутковими, ніж ці ж культури у традиційній системі.

Система смугового землеробства (Strip-till) $[15,22]$, одним із головних завдань якої $є$ збереження вологи, привертає також увагу аграрників. Ця технологія проста і зрозуміла - культиватором Pluribus у зчіпці з гусеничним трактором John Deere обробляється лише посівна зона, грунт між рядками залишається недоторканим. Максимальна глибина обробітку грунту - 15 см. Обробіток грунту та посів відбувається одночасно, щоб підготовлена смуга не пересихала.

На сівалці прикочуючі лапчасті колеса прикочують борозну до половини іiі глибини i, не- 


\section{СІЛЬСЬКЕ ГОСПОДАРСТВО. ЕКОЛОГІЯ}

мов віялом, загортають іï зверху пухким грунтом, що створює шар мульчі, який утримує вологу. Усі агрегати ходять однією технологічною колією, не ущільнюючи грунт по всій площі.

Два важелі, які спонукають виробників обирати нову систему землеробства: клімат і економіка. Це і економічно вигідно: витрати дизельного пального (10-12 л/га), а при традиційній системі - 60-80 л/га, і доцільно агрономічно, оскільки нині збереження вологи є першочерговою проблемою.

При цьому відпрацьовуються і перші уроки переходу на точне землеробство, оскільки внесення добрив у смуги більш раціональне, якісне та доцільне при використанні навігації, адже i для Strip-till вона вкрай необхідна.

Система точного землеробства $[5,22]$ дає можливість компенсувати вплив змін клімату, якщо розглядати поле, як окрему одиницю. Точне землеробство базується на автоматизації процесів і впровадженні інновацій, які дають змогу управляти природними ресурсами, контролювати їх використання та здійснювати оцінку якості різних виробничих процесів.

Основою точного землеробства $є$ картографування і зонування властивостей грунту на полях. На основі цього проводиться диференційоване внесення добрив, зміна норм висіву насіння, диференційоване внесення азоту для мінералізації рослинних решток, дистанційний облік даними тощо.

При цьому використовується нова сільськогосподарська техніка обладнана системами позиціонування високої точності, автоматичним управлінням, географічним картуванням, моніторами, датчиками, інтегрованими електронними комунікаціями.

Для впровадження технології точного землеробства необхідно зібрати дані рівня змінних грунтових властивостей щодо поля, врожаю та мікроклімату, визначити чинники, які обмежують отримання врожаю, шляхом вивчення грунту й особливостей полів господарства (структуру грунту, агрохімічні властивості, тип грунту, рельєф поля, розподіл води тощо). На підставі одержаних даних регулюють норми внесення ресурсів (добрива, насіння, тощо), створюють карти завдання з урахуванням вартості ресурсів і врожаю та з урахуванням потенціалу поля й ефективної врожайності.

Ця система землеробства дає вагомий ефект лише тоді, коли працює кожний ¥ї пункт, коли вона застосована як цілісний організм. Тоді вона дозволяє отримати максимальний урожай за мі- німальних витрат.

Серед сучасних альтернативних систем землеробства відома також біоензимна технологія [21]. Ця технологія є унікальною, адже робить родючими абсолютно неродючі піски пустелі. Автори цієї технології, яку назвали біоензимною, спрямували свої зусилля на запуск і підтримку інтенсивного природного процесу біоценозу без пересичення грунтів тонами мінеральних добрив.

Основою для запуску біоценозу в неродючих грунтах обрано бентоніт, який є добрим сорбентом і поживним елементом для автотрофних бактерій. Він також є добрим гідратантом (один грам бентоніту поглинає до 12 г води). Акумулюючи воду, він набухає, збільшуючи власну масу в 16 разів, тим самим збагачуючи грунт водою.

Щоб дати поживу гетеротрофам, слід додати органічного добрива. Найкращим для цього $\epsilon$ курячий послід. Він запускає і постійно підтримує ланцюг живлення. Для того, щоб збільшити коефіцієнт доступності органіки, курячий послід ферментується оксизином. При цьому зростає коефіцієнт доступності посліду з 30 \% до $100 \%$. За такої доступності вносити на поля 20 т/га курячого посліду немає потреби, достатньо всього 1 т/га.

Внесення субстрату в пустельних експериментах показало покращення хімічного складу грунту за всіма показниками. Внесений бентоніт накопичує вологу, яка надходить протягом року, що дозволяє переживати посухи. Бентоніт вноситься один раз на 7-10 років.

Отже, біоензимна технологія створює оптимальний поживний і водний режим навіть в екстремальних умовах вирощування культурних рослин, і дає можливість отримувати екологічно безпечну продукцію.

Останнім часом все більше матеріалів 3'являється 3 біогенного землеробства $[25,26]$. У його основі лежать нові енергетичні, органічні та біогенні ресурси, організаційно-технологічні та макроструктурні зміни яких можуть значно покращити вологозабезпеченість i продуктивність грунту.

При цьому на землях інтенсивного використання із подрібнених стебел чагарників формується мульчепласт. Це забезпечує усунення дефляції й водної ерозії, формує позитивний водний баланс грунту. Біомаса мульчепласту як додаткова мульча вноситься у розрахунку 10 т/га. Для розкладання мікроорганізмами такої кількості органіки вносяться біодобрива. 


\section{СІЛЬСЬКЕ ГОСПОДАРСТВО. ЕКОЛОГІЯ}

Другим елементом системи $\epsilon$ локальновертикальний тип обробітку грунту. Для швидкого поглинання зливових вод влітку та вод від інтенсивного сніготанення навесні щорічно на 1 $\mathrm{M}^{2}$ площі спеціальним механізмом продавлюють 36 вертикальних дрен діаметром 3 см і глибиною 40 см. Це також $є$ запорукою накопичення вологи й усунення ерозійних процесів.

До системи входять також насадження чагарникових смуг впоперек схилів та суцільні посадки чагарників на малопродуктивних землях 3 еколого-агрохімічним балом менше 30 і схилом понад 3-5 градусів.

Підсумовуючи, зазначимо, що розвиток біогенної системи землеробства може йти шляхом максимального використання агробіоценозами вологоресурсів в умовах великих площ ярів та малопродуктивних земель завдяки мульчепласту, локально-вертикальному обробітку грунту та чагарниковим смугам.

\section{БІБЛІОГРАФІЯ}

1. Австралійські польові уроки. Лоуренс Річмонд про no-till в Україні, наші помилки та перспективи. Зерно. 2017. № 11 (140). С. 24-30.

2. Адаптація агротехнологій до змін клімату: грунтово-агрохімічні аспекти ; за наук. ред. С. А. Балюка, В. В. Медведєва, Б. С. Носка. Харків, 2018. 363 с.

3. Антонець С. С. Шлях до грунтозахисного біологічного землеробства в Україні ; за ред. М. К. Шикули. Київ : Оранта, 2000. С. 54-78.

4. Белецкий Е. Н., Станкевич С. В. Полицикличность, синхронность и нелинейность популяционной динамики насекомых и проблемы прогнозирования : монография. Вена : Premier Publishing s.r.o. Vienna, 2018. 138 c.

5. Броварець О. «Таблиця Менделєєва» для точного землеробства. Зерно. 2018. № 2 (143). C. 322-324.

6. Бучинский И. Е. Засухи, суховеи, пыльные бури на Украине и борьба с ними. Киев : Издательство «Урожай», 1970. 234 с.

7. Григорів Я. Зачарована весна. Рух у напрямку пустелі - перспективи навесні? Зерно. 2019. № 1 (154). С. 71-76.

8. Гридчин B. T. Новые технологии - первый шаг к биологическому земледелию. Белгород : Крестьянское дело. 2012. 248 с.

9. Грифт Д. Р., Монкириф Дж. Ф., Эксерт Д. Дж. Уточненные моменты современного понимания системы земледелия no-till в США. Зерно. 2017. № 10 (139). С. 106-110.
Висновок. Отже, за умов збільшення посушливості клімату необхідно вживати системні та науково обгрунтовані заходи 3 адаптації аграрного виробництва до нових кліматичних умов. Протистояння постійному дефіциту вологи в землеробстві досягається за рахунок накопичення i збереження ii шляхом постійного застосування сучасних енергоресурсовологозберігаючих технологій вирощування сільськогосподарських культур, мінімізації обробітку грунту, скорочення строків проведення весняних польових робіт, i взагалі дотримання регламентів використання усіх технологічних операцій.

Ці заходи сприяють сталому розвитку аграрного сектора України, оскільки вони базуються на принципах золотого правила екології, яке повинно повсякчас впроваджуватися в життя на рівні господарств, - глобальні проблеми екології вирішуються локально.

10. Дегодюк E. Поклик збуреної природи. The Ukrainian Farmer. 2018. № 8 (104). С. 62-64.

11. Золотов В. И. Устойчивость кукурузы к засухе - основы биологии, экологии и сортовой агротехнике. Днепропетровск : Новая идеология, 2010. 274 с.

12. Измаильский $A$. A. Как высохла наша степь ; общ. ред. В. Р. Вильямса. Москва Ленинград : ОГИЗ - Сельхозгиз, 1937. 81 с.

13. Іващченко О. Подітися ніде. The Ukrainian Farmer. 2017. № 8. С. 74-76.

14. Мельник $C$. Зміни клімату вже позначаються на сільському господарстві. Агрополітика. 2018. № 4. C. 8-11.

15. Павлюк I. 1000 центнерів зі... смужок. Зерно. 2017. № 11 (140). С. 132-136.

16. Писаренко В. М., Антонец̧ь А. С., Лук'яненко Г. В., Писаренко П. В. Система органічного землеробства агроеколога Семена Антонця. Полтава, 2017. 124 с.

17. Погосян $X$. П. Общая циркуляция атмосферы. Ленинград : Гимиз, 1959. 394 с.

18. Районування території України за рівнем забезпеченості гідротермічними ресурсами та обсягами використання сільськогосподарських меліорацій / Ю. О. Тараріко, Р. В. Сайдак, Ю. В. Сорока, С. В. Вітвіцький. Київ : ЦП «Компринт», 2015. 62 с.

19. Рекомендации по борьбе с засухой в районах юга Украинской ССР (Одобрено научной сессией АН ССРИ ВАСХНИЛ 31 января-3 февраля 1973 г.). Москва : Колос, 1973. 233 с. 


\section{СІЛЬСЬКЕ ГОСПОДАРСТВО. ЕКОЛОГІЯ}

20. Рэнди Л. А. Можно ли обойтись без почвообработки и гербицидов? Зерно. 2016. № 2 (129). C. $72-82$.

21. Самойленко I. Запуск біоценозу. Зерно. 2017. № 12 (141). С. 30-35.

22. Самойленко I. Смугастий рейс. На шляху до точного землеробства. Зерно. 2018. № 4 (145). C. 42-46.

23. Селянинов T. Т. Происхождение и динамика засух. В кн.: Засухи в СССР. Их происхождение, повторяемость и влияние на урожай. Ленинград : Гидрометиздат, 1958. С. 5-29.

24. Старостишин В. Прошу прощення в землі, в полів... The Ukrainian Farmer. 2017. № 8. C. $66-69$.

25. Тимофеев М. М. Біогенне землеробство в аспекті енергетичних ресурсів. Бюлетень зернового господарства. 2010. № 38. С. 154-158.

\section{REFERENCES}

1. Avstraliiski polovi uroky. Lourens Richmond pro no-till v Ukraini, nashi pomylky ta perspektyvy [Australian field lessons. Lawrence Richmond about no-till in Ukraine, our mistakes and prospects] (2017). Zerno, 11 (140), pp. 24-30 [In Ukrainian].

2. Baliuka, S. A., Medvedeva, V. V., Noska, B. S. (Eds.) (2018). Adaptatsiia ahrotekhnolohii do zmin klimatu: gruntovo-ahrokhimichni aspekty [Adaptation of agrotechnologies to climate change: soil-agrochemical aspects]. Kharkiv[In Ukrainian].

3. Antonets, S. S. (2000). Shliakh do gruntozakhysnoho biolohichnoho zemlerobstva $v$ Ukraini [The way to soil protection of biological agriculture in Ukraine]. M. K. Shykuly (Ed.), (pp. 54-78). Kyiv: Oranta [In Ukrainian].

4. Beletskyi, E. N., Stankevych, S. V. (2018). Policiklichnost', sinhronnost' $i$ nelinejnost' populyacionnoj dinamiki nasekomyh i problemy prognozirovaniya : monohrafyia [Polycyclicity, synchronicity and nonlinearity of the population dynamics of insects and problems of forecasting: monograph]. Vena: Premier Publishing s.r.o. Vienna [In Russian].

5. Brovarets, O. (2018). «Tablytsia Mendelieieva» dlia tochnoho zemlerobstva [«Mendeleyev's Table» for precise agriculture]. Zerno, 2 (143), pp. 322-324 [In Ukrainian].

6. Buchynskyi, Y. E. (1970). Zasuhi, suhovei, pyl'nye buri na Ukraine i bor'ba s nimi [Droughts, dry winds, dust storms in Ukraine and the fight against them]. Kyev: Yzdatelstvo «Urozhai» [In Russian].
26. Тимофеев М. М., Вінюков О. О., Бондарева $O$. Б. Взаємодія біогенних та технікотехнологічних чинників при формуванні сталих агробіоценозів. Збалансоване природокористування. 2017. № 1. С. 43-49.

27. Yasnolob I., Chayka T., Aranchiy V., Gorb O., Dugar T. Mycorrhiza as a biotic factor, influencing the ecosystem stability. Ukrainian Journal of Ecology. 2018. № 8(1). P. 363-370. DOI : http://dx.doi.org /10.15421/2018\%25x URL : http://ojs.mdpu.org.ua/ index.php/biol/article/view/223.

28. Yasnolob I. O., Pysarenko V. M., Chayka T. O., Gorb O. O., Pestsova-Svitalka O. S., Kononenko Zh. A., Pomaz O. M. Ecologization of tillage methods with the aim of soil fertility improvement. Ukrainian Journal of Ecology. 2018. № 8 (2). P. 280-286. DOI : 10.15421/2018_339 URL : http://ojs.mdpu.org.ua/index.php/biol/article/ view/_339.

7. Hryhoriv, Ya. (2019). Zacharovana vesna. Rukh u napriamku pusteli - perspektyvy navesni? [Enchanted Spring. Movement towards the desert Prospects in the Spring?]. Zerno, 1 (154), pp. 71-76 [In Ukrainian].

8. Hrydchyn, V. T. (2012). Novye tekhnologii- pervyj shag $k$ biologicheskomu zemledeliyu [New technologies are the first step towards biological agriculture]. Belhorod: Krestianskoe delo [In Russian].

9. Hryft, D. R., Monkyryf, Dzh. F., Eksert, D. Dzh. (2017). Utochnennye momenty sovremennogo ponimaniya sistemy zemledeliya notill v SSHA [Refined moments of the modern understanding of the no-till farming system in the USA]. Zerno, 10 (139), pp. 106-110 [In Russian].

10. Dehodiuk, E. (2018). Poklyk zburenoi pryrody [Call of perturbed nature]. The Ukrainian Farmer, 8 (104), pp. 62-64 [In Ukrainian].

11. Zolotov, V. Y. (2010). Ustojchivost' kukuruzy $k$ zasuhe - osnovy biologii, ehkologii $i$ sortovoj agrotekhnike [Resistance of corn to drought - the basis of biology, ecology and varietal agrotechnology]. Dnepropetrovsk: Novaia ydeolohyia [In Russian].

12. Yzmaylskyi, A. A. (1937). Kak vysohla nasha step' [How our Steppe dried] ; obshch. red. V. R. Vyliamsa. Moskva-Lenynhrad: OHYZ Selkhozghyz [In Russian].

13. Ivashchenko, O. (2017). Poditysia nide [Nowhere to go]. The Ukrainian Farmer, 8, pp. 74-76 [In Ukrainian].

14. Melnyk, S. (2018). Zminy klimatu vzhe 
poznachaiutsia na silskomu hospodarstvi [Climate change already affect agriculture]. Ahropolityka, 4, pp. 8-11 [In Ukrainian].

15. Pavliuk, I. (2017). 1000 tsentneriv zi... smuzhok [1000 quintals of stripes]. Zerno, 11 (140), pp. 132-136 [In Ukrainian].

16. Pysarenko, V. M., Antonets, A. S., Lukianenko, H. V., Pysarenko, P. V. (2017). Systema orhanichnoho zemlerobstva ahroekoloha Semena Antontsia [Organic Farming System of Agroecologist Semen Antonets]. Poltava [In Ukrainian].

17. Pohosian, Kh. P. (1959). Obshchaya cirkulyaciya atmosfery [The general circulation of the atmosphere]. Lenynhrad: Hymyz [In Russian].

18. Tarariko, Yu. O., Saidak, R. V., Soroka, Yu. V., Vitvitskyi, S. V. (2015). Raionuvannia terytorii Ukrainy za rivnem zabezpechenosti hidrotermichnymy resursamy ta obsiahamy vykorystannia silskohospodarskykh melioratsii [Dissemination of the territory of Ukraine by the level of availability of hydrothermal resources and volumes of use of agricultural land reclamation]. Kyiv: TsP «Komprynt» [In Ukrainian].

19. Rekomendatsyy po borbe $s$ zasukhoi $v$ raionakh yuha Ukraynskoi SSR (Odobreno nauchnoi sesyei AN SSRY VASKhNYL 31 yanvaria3 fevralia 1973 h.) [Recommendations for combating drought in the areas of the South of the Ukrainian SSR (Approved by the scientific session of the Academy of Sciences of the SSRI of All-Union Academy of Agricultural Sciences named after V. I. Lenin January 31-February 3, 1973)]. Moskva: Kolos [In Russian].

20. Rendy, L. A. (2016). Mozhno ly oboitys bez pochvoobrabotky y herbytsydov? [Is it possible to do without tillage and herbicides?]. Zerno, 2 (129), pp. 72-82 [In Russian].

21. Samoilenko, I. (2017). Zapusk biotsenozu [Launch of biocenosis]. Zerno, 12 (141), pp. 30-35 [In Ukrainian].

22. Samoilenko, I. (2018). Smuhastyi reis. Na shliakhu do tochnoho zemlerobstva [Striped flight. On the way to exact farming]. Zerno, 4 (145), pp. 42-46 [In Ukrainian].

23. Selianynov, T. T. (1958). Proyskhozhdenye y dynamyka zasukh. V KN.: Zasukhy v SSSR. Ykh proyskhozhdenye, povtoriaemost y vlyianye na urozhai [Origin and dynamics of droughts. In the book: Drought in the USSR. Their origin, repeatability and influence on the crop], (pp. 5-29). Lenynhrad: Hydrometyzdat [In Russian].

24. Starostyshyn, V. (2017). Proshu proshchennia $\mathrm{v}$ zemli, $\mathrm{v}$ poliv... [I ask forgiveness in the land, in the fields...]. The Ukrainian Farmer, 8, pp. 66-69 [In Ukrainian].

25. Tymofeev, M. M. (2010). Biohenne zemlerobstvo $\mathrm{V}$ aspekti enerhetychnykh resursiv [Biogenic agriculture in terms of energy resources]. Biuleten zernovoho hospodarstva, 38, pp. 154-158 [In Ukrainian].

26. Tymofeev, M. M., Viniukov, O. O., Bondareva, O. B. (2017).Vzaiemodiia biohennykh ta tekhniko-tekhnolohichnykh chynnykiv pry formuvanni stalykh ahrobiotsenoziv [Interaction of biogenic and technical and technological factors in the formation of stable agrobiocenoses]. Zbalansovane pryrodokorystuvannia, 1, pp. 43-49 [In Ukrainian].

27. Yasnolob, I., Chayka, T., Aranchiy, V., Gorb, O., Dugar, T. (2018). Mycorrhiza as a biotic factor, influencing the ecosystem stability. Ukrainian Journal of Ecology, 8(1), pp. 363-370. DOI : http://dx.doi.org/10.15421/2018\%25x, URL : http://ojs.mdpu.org.ua/index.php/biol/article/view/_ 223 [In English].

28. Yasnolob, I. O., Pysarenko, V. M., Chayka, T. O., Gorb, O. O., Pestsova-Svitalka, O. S., Kononenko, Zh. A., Pomaz, O. M. (2018). Ecologization of tillage methods with the aim of soil fertility improvement. Ukrainian Journal of Ecology, 8(2), pp. 280-286. DOI : 10.15421/2018_339, URL : http://ojs.mdpu.org.ua/index.php/biol/article /view/_339 [In English].

Писаренко В. М., Писаренко П. В., Писаренко В. В., Горб О. А., Чайка Т. А. Засуха в контексте изменений климата Украинь

Цель статьи - обосновать необходимость внедрения системных и научно обоснованных мероприятий по адаптачии аграрного производства к новым климатическим условиям в связи с увеличением повторяемости засух.

Методика исследования. Методологической основой исследования были следующие научные методы: историко-диалектический, анализа и синтеза, теоретический поиск и абстрактнологический, математического и статистического анализа на основе результатов исследований, проведенных на сельскохозяйственных угодьях ЧП «Агроэкология».

Результаты исследования. Исследованы теории изменений климата, с которыми связаны засу- 


\section{СІЛЬСЬКЕ ГОСПОДАРСТВО. ЕКОЛОГІЯ}

хи: влияние солнечной активности, влияние космических факторов, антропогенное влияние на природу. Обоснована цеелесообразность разработки адаптационных мероприятий в технологии сельскохозяйственного производства, которые позволят уменьшить негативное влияние погоды, и технологические мероприятия по накоплению, сохранению и рациональному использованию воды, особенно в условиях засухи. Показано влияние на сохранение влаги, урожайность и рентабельность аграрного производства различных систем земледелия: интенсивной, органической, nо-till, strip-till, точного земледелия, биоензимной технологии, биогенного земледелия. Доказано, что в условиях изменения климата все актуальнее становятся исследования влагосберегающих систем земледелия, одной из которых является органическое земледелие.

Элементы научной новизны. Определены особенности агротехнических приемов, способствующзих накоплению, сохранению и рациональному использованию почвенной влаги в условиях различньх систем земледелия.

Практическая значимость. Проведенные исследования влияния высоты снежного покрова на запасы влаги в метровом слое почвы при системе органического земледелия свидетельствуют о значительной роли снегозадержания. Раскрыто ичелесообразность в регулировании влагообеспеченности культур таких агротехнологических мероприятий: создание кулис для задержки снега, использование лесополос, внедрение севооборотов, правильное структурирование посевных плошадей, минимальная обработка почвы, использование органических удобрений, мульчирование поверхности поля.

Ключевые слова: засуха, изменение климата, влагообеспеченность почвы, урожайность, сельскохозяйственные культуры, органическое земледелие, нулевое воздельвание почвы, система полосового земледелия, система точного земледелия, биоэнзимная технология, биогенное земледелие.

Писаренко Виктор Никитович - доктор сельскохозяйственных наук, профессор, заведующий кафедрой защиты растений, заслуженный деятель науки и техники Украины, Полтавская государственная аграрная академия, ул. Сковороды, 1/3, м. Полтава, 36003, Украина, e-mail: kafedra.zahysturoslyn@ukr.net, ORCID ID: 0000-0002-4915-265X.

Писаренко Павел Викторович - доктор сельскохозяйственных наук, профессор, профессор кафедры экологии, сбалансированного природопользования и защиты окружающей среды, первый проректор, академик инженерной Академии наук Украины, Полтавская государственная аграрная академия, ул. Сковороды, 1/3, м. Полтава, 36003, Украина, e-mail: pavlo.pysarenko@pdaa.edu.ua, ORCID ID: 0000-0002-4915-265X.

Писаренко Владимир Викторович - доктор экономических наук, профессор, заведующий кафедрой маркетинга, Полтавская государственная аграрная академия, ул. Сковороды, 1/3, м. Полтава, 36003, Украина, e-mail: volodymyr.pysarenko@pdaa.edu.ua, ORCID ID: 0000-0002-9484-3476.

Горб Олег Александрович - кандидат сельскохозяйственных наук, доцент, профессор кафедры экологии, сбалансированного природопользования и защиты окружающей среды, проректор по научно-педагогической, научной работе, член-корреспондент инженерной Академии наук Украины, Полтавская государственная аграрная академия, ул. Сковороды, 1/3, м. Полтава, 36003, Украина, е-таil: gorb@pdaa.edu.ua, ORCID ID: 0000-0002-3141-8114.

Чайка Татьяна Александровна - кандидат экономических наук, начальник редакционноиздательского отдела, Полтавская государственная аграрная академия, ул. Сковороды, 1/3, м. Полтава, 36003, Украина, e-mail: chayka_ta@ukr.net, ORCID ID: 0000-0002-5980-7517.

Pysarenko V. M., Pysarenko P. V., Pysarenko V. V., Gorb O. O., Chaika T. O. Droughts in the context of climate changes in Ukraine

The purpose of the article is to prove the necessity of introducing systemic and scientifically grounded measures for the adaptation of agrarian production to new climatic conditions in connection with the increasing drought recurrences.

Methods of research. The following scientific methods were the methodological basis of the research: historical-dialectical, analysis and synthesis, theoretical search and abstract-logical, mathematical and statistical analysis based on the research results conducted on farm lands of the private enterprise "Agroecology".

The research results. The theories of climate changes, which are connected with droughts - the influence of solar activity, cosmic factors, anthropogenic impact on nature, have been investigated. The expedi-

№ 1 • 2019 • ВІСНИК Полтавської державної аграрної академії 


\section{СІЛЬСЬКЕ ГОСПОДАРСТВО. ЕКОЛОГІЯ}

ency of developing adaptation measures in agricultural production technology, which will enable to reduce the negative influence of weather, and technological measures on accumulation, conservation and rational use of moisture, especially in conditions of drought, has been substantiated. The impact on moisture preservation, productivity and profitability of agrarian production of different farming systems (intensive, organic, no-till, strip-till, precision farming, bio-enzyme technology, biogenic farming) has been shown. It is proved that the research of moisture-conserving farming systems, one of which is organic farming, in the conditions of climate change is topical.

The elements of scientific novelty. The peculiarities of agro-technical methods favoring the accumulation, conservation and rational use of soil moisture, under the conditions of different farming systems have been determined.

Practical significance. The studies of snow cover height effect on moisture reserves in a meter layer of soil at organic farming system have been conducted and they have shown the significant role of snow retention. The expediency of regulating crop moisture supply with such agro-technological measures as creating gates for snow retention, using forest bands, introducing crop rotation, correct structuring of sown areas, minimal soil tillage, using organic fertilizers, mulching field surface has been disclosed.

Key words: drought, climate change, soil moisture supply, yield, crops, organic farming, zero soil tillage, system of strip farming, precision farming system, bio-enzyme technology, biogenic farming.

Pysarenko Viktor Mykytovych - Doctor of Agricultural Sciences, Professor, Head of the Department of Plant Protection, Honored Worker of Science and Technology of Ukraine, Poltava State Agrarian Academy, 1/3, Skovorody st., Poltava, 36003, Ukraine, e-mail: kafedra.zahystu-roslyn@ukr.net, ORCID ID: 00000002-4915-265X.

Pysarenko Pavlo Viktorovych - Doctor of Agricultural Sciences, Professor, Professor of the Department of Ecology, Balanced Nature Management and Environmental Protection, Academician of the Engineering Academy of Ukraine, First Vice-Rector, Poltava State Agrarian Academy, 1/3, Skovorody st., Poltava, 36003, Ukraine, e-mail: pavlo.pysarenko@pdaa.edu.ua, ORCID ID: 0000-0002-4915-265X.

Pysarenko Volodymyr Viktorovych - Doctor of Economics, Professor, Head of the Department of Marketing, Poltava State Agrarian Academy, 1/3, Skovorody st., Poltava, 36003, Ukraine, e-mail: volodymyr.pysarenko@pdaa.edu.ua, ORCID ID: 0000-0002-9484-3476.

Gorb Oleh Oleksandrovych - Candidate (PhD) of Agricultural Sciences, Associate Professor, Professor of the Department of Ecology, Balanced Nature Management and Environmental Protection, Corresponding Member of the Engineering Academy of Ukraine, Vice-Rector of Scientific and Pedagogical, Scientific Work, Poltava State Agrarian Academy, 1/3, Skovorody st., Poltava, 36003, Ukraine, e-mail: gorb@pdaa.edu.ua, ORCID ID: 0000-0002-3141-8114.

Chaika Tetiana Oleksandrivna - Candidate $(\mathrm{PhD})$ of Economic Sciences, Head of the Editorial and Publishing Department, Poltava State Agrarian Academy, 1/3, Skovorody st., Poltava, 36003, Ukraine, e-mail: chayka_ta@ukr.net, ORCID ID: 0000-0002-5980-7517.

Стаття надійшла до редакції 22.02.2019 р.

Бібліографічний опис для цитування :

Писаренко В. М., Писаренко П. В., Писаренко В. В., Горб О. О., Чайка Т. О. Посухи в контексті змін клімату України. Вісник ПДАА. 2019. № 1. С. 134-146.

DOI 10.31210/visnyk2019.01.15

(C) Писаренко Віктор Микитович, Писаренко Павло Вікторович, Писаренко Володимир Вікторович, Горб Олег Олександрович, Чайка Тетяна Олександрівна, 2019 